This is the author's final, peer-reviewed manuscript as accepted for publication. The publisher-formatted version may be available through the publisher's web site or your institution's library.

\title{
Resistance to Wheat streak mosaic virus identified in synthetic wheat lines
}

Jessica L. Shoup Rupp, Zachary G. Simon, Beth Gillett-Walker, and John P. Fellers

\section{How to cite this manuscript}

If you make reference to this version of the manuscript, use the following information:

Shoup Rupp, J. L., Simon, Z. G., Gillett-Walker, B., \& Fellers, J. P. (2014). Resistance to Wheat streak mosaic virus identified in synthetic wheat lines. Retrieved from http://krex.ksu.edu

\section{Published Version Information}

Citation: Shoup Rupp, J. L., Simon, Z. G., Gillett-Walker, B., \& Fellers, J. P. (2014). Resistance to Wheat streak mosaic virus identified in synthetic wheat lines. Euphytica, 198(2), 223-229.

Copyright: @ Springer Science+Business Media Dordrecht (outside the USA) 2014

Digital Object Identifier (DOI): doi:10.1007/s10681-014-1095-3

Publisher's Link: http://link.springer.com/article/10.1007/s10681-014-1095-3

This item was retrieved from the K-State Research Exchange (K-REx), the institutional repository of Kansas State University. K-REx is available at http://krex.ksu.edu 


\title{
Submission to Euphytica.
}

Resistance to Wheat streak mosaic virus identified in synthetic wheat lines.

Jessica L. Shoup Rupp ${ }^{1}$, Zachary G. Simon ${ }^{1}$, Beth Gillett-Walker ${ }^{1}$, and John P. Fellers ${ }^{2}$.

1. Department of Plant Pathology, Kansas State University, Manhattan, KS 66506

2. USDA-ARS Hard Winter Wheat Genetics Research Unit, Manhattan, KS 66506

\section{Corresponding author:}

\author{
John P. Fellers \\ USDA-ARS HWWGRU \\ 4008 Throckmorton Hall \\ Manhattan, KS 66506 \\ (785) 532-2367 \\ john.fellers@ars.usda.gov
}

\begin{abstract}
Abbreviations: WSMV, Wheat streak mosaic virus; CIMMYT, International Maize and Wheat Improvement Center, Mexico; ELISA, enzyme linked immunosorbant assay Key words: virus resistance, Wheat streak mosaic virus, synthetic wheat lines Mention of a trademark of a proprietary product does not constitute a guarantee of warranty of the product by the United States Department of Agriculture, and does not imply its approval to the exclusion of other products that may also be suitable. USDA is an equal opportunity provider and employer
\end{abstract}




\begin{abstract}
Wheat streak mosaic virus (WSMV) is an important pathogen in wheat that causes significant yield losses each year. WSMV is typically controlled using cultural practices such as the removal of volunteer wheat. Genetic resistance is limited. Until recently, no varieties have been available with major resistance genes to WSMV. Two resistance genes have been derived from Thinopyrum intermedium through chromosome engineering, while a third gene was transferred from bread wheat through classical breeding. New sources of resistance are needed and synthetic wheat lines provide a means of accessing genetic variability in wheat progenitors. A collection of wheat synthetic lines was screened for WSMV resistance. Four lines, 07-SYN-27, -106, -164, and -383 had significant levels of resistance. Resistance was effective at $18{ }^{\circ} \mathrm{C}$ and virus accumulation was similar to the resistant control, WGGRC50 containing Wsm1. At 25 ${ }^{\circ} \mathrm{C}$, resistance was no longer effective and virus accumulation was similar to the susceptible control, Tomahawk.
\end{abstract}




\section{INTRODUCTION.}

Each year, wheat production around the world is faced with many abiotic and biotic stresses, including viruses. Wheat streak mosaic virus (WSMV) is found throughout the Great Plains of North America (Burrows et al. 2009) and throughout the world, wherever wheat (Triticum ssp.) is grown (Slykuis and Bell 1963; Ellis et al. 2003). WSMV, belonging to the Potyviridae family (Stenger et al. 1998), is transmitted by the wheat curl mite, Aceria tosichella Keifer (Slykhuis 1955) as well as, infrequently, by seed (Dwyer et al. 2007). Symptoms include stunting, mosaic patterns in the leaves, root mass reductions and yield reductions (Rahman et al. 1974; Price et al. 2010). Crop losses due to WSMV ranged from a trace to $13 \%$ in Kansas from 1976 to 2000 (Bockus et al. 2001); however, complete field losses have been reported. The predominant means of reducing the incidence of the virus are through the utilization of limited genetic resources and the cultural practice of controlling volunteer wheat.

The most economical way to combat viruses is through genetics. Maize (Zea mays $L$ ) is a host of WSMV and has three single dominant resistance genes available for resistance (McMullen et al. 1994; Jones et al. 2011). Unfortunately, only a single dominant resistance gene, Wsm2 (Haley et al. 2002; Siefers et al. 2006; Martin 2007; Liu et al. 2011), and minor resistance or tolerance (Rahman et al. 1974; Martin et al. 1976; Seifers and Martin 1988) has been found in hexaploid bread wheat (Triticum aestivum L.). There are also genes for resistance to wheat curl mite which is an alternate method to reduce the incidence of WSMV through control of the vector (Martin et al. 1984). Without good sources of resistance in bread wheat, geneticists have turned to grass relatives of wheat. Significant resistance to WSMV has been found in Thinopyrum 
ponticum (Podp.) Buckworth and Dewey and Th. intermedium (Host) Buckworth and Dewey (Lay et al. 1971, Stoddard et al. 1987; Friebe et al., 1996, 2009). Wsm1 and Wsm3, which were were derived from different compensating Robertsonian translocations from Th. intermedium, are located on chromosomes T4DL-4J ${ }^{\mathrm{S}} \mathrm{S}$ and T7BS$7 \mathrm{~S} \# 3 \mathrm{~L}$, respectively, and are currently being used to develop resistance wheat varieties (Gill et al. 1995; 2008; Friebe 1996; 2009; Liu et al. 2011).

Due to the difficulty in assessing viral resistance and the environmental variables affecting symptoms, germplasm has not been extensively screened. When resistance is found, however, it is often in wheat relatives which are difficult to cross to and do not recombine well with the hexaploid wheat genome. Wheat relatives contain an immense repository of genetic diversity which can be captured through the use of synthetic hexaploids (Zohary et al. 1969; Cox 1998). The International Center for Maize and Wheat Improvement (CIMMYT) in Mexico has developed a collection of synthetic wheat lines as a means of accessing traits in wheat wild relatives (Mujeeb-Kazi et al. 2001a; 2001b). Each were derived from a cross between a tetraploid, either T. durum or T. diccoides, and a diploid, such as Aegilops tauschii $(2 \mathrm{n}=2 \mathrm{x}=14 \mathrm{DD})$, and have been shown to have 39\% more genetic diversity than common hexaploid wheat (Lage et al. 2003). Resistance to stripe rust (Ma et al. 1995), greenbug (Lage et al. 2002), and Russian wheat aphid (Lage et al. 2004) has been gained through the use of synthetics. Synthetics are currently playing a significant role in CIMMYT-derived varieties around the world (Warburton et al. 2006). To our knowledge, the CIMMYT synthetic collection has not been evaluated for the presence of WSMV resistance. Therefore, the objective 
for this work was established to evaluate the collection and begin transferring resistance to adapted varieties.

\section{MATERIALS AND METHODS}

Virus and Plant material. WSMV-Sidney 81 was obtained from Dr. William Bockus (Kansas State University, Department of Plant Pathology) and maintained in the susceptible hard winter wheat cultivar Tomahawk (PI 478006). The virus was inoculated using a finger rub/swipe technique by applying $\sim 40 \mu \mathrm{l}$ of infected plant sap (100 mg of desiccated leaf tissue in $100 \mu \mathrm{l}$ of $0.02 \mathrm{M}$ sodium phosphate buffer, $\mathrm{pH} 7.4$ ) to the second or third leaf of 2 week old seedlings. Carborundum was dusted lightly onto the second leaf and approximately $40 \mu \mathrm{l}$ of inoculum was placed above the carborundum. The leaf was then pinched between the thumb and forefinger and the plant sap was pulled down the length of the leaf several times. The virus was maintained by reinoculating new seedlings every 4 weeks. Virus purity was evaluated by enzyme linked immunosorbant assay (ELISA) and inoculation onto the wheat cultivar 'RonL' which is resistant to WSMV (Martin et al. 2007). WSMV infected leaf tissue was stored by placing 3-6 cm sections of leaves onto a bed of Drierite desiccant (Hammond Drierite, Xenia, OH) covered by Whatman 1, 90 mm filter paper (Cat no 1001-090), in a Nunc 15x100 mm petri dish (Nalge, Rochester, NY), and stored at $4{ }^{\circ} \mathrm{C}$ (Dr. William Bockus, personal communication).

Initial screening of synthetic lines. Seed from 412 synthetic lines (Mujeeb-Kazi et al., 2001a; 2001b) was provided by Dr. Art Klatt, (Oklahoma State University) and the Wheat Genetics and Genomics Resource Center (Kansas State University). Lineages can 
be found at http://www.k-state.edu/wgrc/Germplasm/synthetics.html (Verified January 9, 2014). All synthetic lines were initially screened by planting five seeds of each line in 10 cm pots containing Metro Mix 360 soil medium (SunGro, Vancover, BC). Plants were planted the first week of November in the greenhouse at a temperature of $20^{\circ} \mathrm{C}, 16 \mathrm{~h}$ day length under high-pressure sodium lamps. At the three-leaf stage, plants were inoculated as before. Three plants were inoculated with the virus and two were mock-inoculated with carborundum and phosphate buffer only. Fourteen days later, the same plants were inoculated a second time using the same procedure. Twenty-one days post second inoculation plants were scored using a numerical scale $0-5$, with 0 being no symptoms and 5 being severe symptoms.

Tissue samples were taken at this time from the youngest leaf of each of the infected plants. One inch of tissue was collected from mid leaf and placed into a $2 \mathrm{ml}$ screw cap tube (LabSource, Romeoville, IL). Wheat tissue was evaluated for the presence of WSMV using double antibody sandwich (DAS) ELISA assay. The tissue was macerated by placing a 1/4" ceramic bead (MP Biomedical, Solon, $\mathrm{OH}$ ) in the tube with $300 \mu$ of general extraction buffer (Agdia, Elkhart, IN). The tubes were placed in an MP Fastprep $24^{\circledR}$ machine (MP Biomedical) at $6 \mathrm{~m} / \mathrm{s}$ for 20 seconds and spun in a microfuge at $15,000 \times \mathrm{g}$. An additional $700 \mathrm{uL}$ was added to the tube. The tube was then vortexed for 15 seconds and microfuged for 30 seconds at 15,000 $x \mathrm{~g}$. Supernatant was applied to WSMV Pathoscreen ELISA plates (Cat no. PSA47001) and the protocol was followed. Plates were read using a spectrophotometer (Bio-Tek, Winooski, VT) at $\mathrm{Abs}_{405}$.

Greenhouse screens of selected lines. 
Thirty-one lines from the initial screen were selected based on visual indications of reduced symptoms and tested in the greenhouse. Lines were planted 5 seeds to a 15 cm square pot containing Metro Mix 360 soil medium. Plants were maintained, inoculated and scored as before. The experiment was repeated four times, over two years, twice in the fall greenhouses where temperatures ranged from $22-25{ }^{\circ} \mathrm{C}$ and twice in the spring greenhouses where temperatures were maintained from $16-19{ }^{\circ} \mathrm{C}$. Temperature averages were taken from greenhouse recorders to determine temperature for different seasons and data analysis. Pots that contained plants that had phenotypic visual scores of 2 or below and viral titer below an $\mathrm{Abs}_{405}$ value of 3 (3 was the maximum measurable value of the spectrophotometer) were then separated and analyzed via ELISA individually. Statistically significant resistance was determined by comparing ELISA values of the synthetic lines versus both susceptible and resistant controls. Statistical analysis was performed using SAS version 9.2 (SAS Institute, Cary, NC).. The results were analyzed using a generalized linear model. The best suited pre-planned statistical analysis for this type of experiment was considered to be Dunnett's adjustment (Dunnett 1955) and was performed to compare each synthetic line with each of the control lines at a significance level of 0.05 and 0.10 . Resistant cultivars RonL, KS93WGRC27 (PI583794; Gill et al. 1995), KS08WGGRC50 (Gill et al. 2008), and susceptible cultivars Bobwhite and Tomahawk were used as control comparisons in the adjustments. 
WSMV is a significant disease in wheat that causes economic losses each year (Christian and Willis 1993). Unfortunately, the level of resistance is low and the number of resistance genes in bread wheat $(2 \mathrm{~N}=6 \mathrm{X}=42$ AABBDD) germplasm is very limited in land races or common varieties. The current sources are mostly distant relatives of wheat (McKinney and Sando 1951). By developing synthetic varieties, breeders are able to access new sources of genetic variation in many of the diploid and tetraploid progenitors (Cox 1998). In this study, 412 synthetic lines were evaluated (Mujeeb et al. 2001a and b) for resistance to WSMV.

Lines were initially screened in the greenhouse during the Fall of 2010. Inoculated plants were re-inoculated 14 days post first inoculation to insure infection. As a measure of resistance, the intensity of the WSMV symptoms leaves were visually scored 21 days post second inoculation and compared to the resistant KS08WGGRC50 and susceptible Tomahawk controls. KS08WGGRC50 did not display any symptoms indicative of WSMV infection, while Tomahawk displayed a weak yellowing, mosaics, and streaking in the second and third leaf above the inoculated leaf (Figure 1).

Symptoms were very prominent in the majority of the tested lines and were extreme in a few of the lines. ELISA was used as a measure of the viral titer. Thirty-one lines were identified with reduced symptomology and titer (data not shown).

The 31 were retested in replicated trials to confirm the initial screening. Lines were planted in the greenhouse in the Falls of 2011 and 2012 and in the Winters of 2012 and 2013. During the fall, greenhouse temperatures ranged from $22-25^{\circ} \mathrm{C}$ and all of the lines displayed some level of symptoms, while in the winter tests, greenhouse temperatures ranged from $16-19^{\circ} \mathrm{C}$ and several of the lines displayed reduced symptoms 
at 21 days post second inoculation. Using Dunnett's test across the four replications, significant phenotypic resistance was found at the 0.05 level in lines SYN-164, -283, 358, -376, and -383 (Table 1). Several lines were also significant at the 0.10 level. Because of a trend for higher ratings at higher temperatures, it was hypothesized that the resistance may be temperature dependent. Previous studies have shown that $W s m 1$, Wsm2, and an unnamed gene in KS03HW12 (Siefers et al. 2007) are ineffective at temperatures above $22{ }^{\circ} \mathrm{C}$ (Seifers et al. 1995; 2007; Lu et al. 2011).

To test this hypothesis, three environments were tested. The first was in a growth chamber at $18{ }^{\circ} \mathrm{C}$, the second was a growth chamber at $25{ }^{\circ} \mathrm{C}$ and the third was a greenhouse at temps between $22-25{ }^{\circ} \mathrm{C}$. Five plants from each line were grown in each environment inoculated as before. Tissue was pooled from all five plants and tested by ELISA. All of the lines in the $25^{\circ} \mathrm{C}$ growth chamber and in the greenhouse were susceptible to WSMV (Table 1). However, four lines, 07 SYN-27, -106, -297, and -383 had little or no WSMV (Figure 1, Table 1). Levels of viral antigen in these lines were similar to KS08WGGRC50 (Table 1). Three lines, 07-SYN-109, -209, and 234, had reduced viral antigen levels when compared to Tomahawk, but were not significant in visual ratings at either the 0.1 or 0.05 level. Also, lines such as $07-\mathrm{SYN}-141$ and -163 , were significant at the 0.1 level, but did not have a reduction in viral antigen. It is believed that lines having significant resistance based on visual scores but with no reduction in virus accumulation, such as SYN 283, are likely due to the nature of the phenotype of the synthetic line. Several synthetic lines have thicker leaves and darker color and symptoms are more difficult to accurately rate. 
It is not known at this time which of the three hexaploid genomes are providing the resistance. Each of the resistant lines has parentage collected from different regions of the world. Two of the original 31 lines, - 109 and - 358, share DOY1 as common tetraploid wheat parent (Table 2), but only -109 was resistant. It could be postulated that the resistance is from the Ae.tauschii genome, as this has been the resistance source to many of other pathogens. The Wheat soil bourne mosaic virus resistance QTL, QSbv.ksu5D, was transferred to common wheat and was on the D genome of the synthetic line 07SYN-16 (CIGM87.2775-1B-0PR-0B; Altar/Ae. tauchii WX193; Narasimhamoorthy et al. 2006). Greenbug (Lage et al. 2002) and stem rust resistance (Ma et al. 1995) were also on the $\mathrm{D}$ genome. However, the naturally occurring gene, $W_{s m} 2$, was mapped to the $\mathrm{B}$ genome (Lu et al. 2011) and the other genes $W s m 1$ and $W s m 3$ are intergenic transfers from wheatgrass.

All of the currently known WSMV resistance genes are sensitive to temperature and have certain limitations to their usefulness in wheat. However, seedling, fall planted winter wheat is most susceptible as the vector moves from volunteer wheat growing over the summer. Having a level of resistance in the cooler weather provides a level of protection that is still useful to breeders. The new sources that we have identified are also temperature sensitive (Figure 2) and until the genes are cloned, the gene-protein characteristics will not be known. Suffice to say, temperature is sure to affect proteinprotein interaction, protein binding, membrane conformation, and virus movement. In summary, 412 synthetic wheat lines from CIMMYT have been screened and four lines were identified with temperature sensitive WSMV resistance. The genome source is 
unknown, however, crosses are now being made for mapping and germplasm

development.

\section{ACKNOWLEDGMENTS:}

Z.S. and B. G-W. began this work as part of their undergraduate research project at

Kansas State University. The authors would like to thank Drs. Bernd Friebe and Perry

Gustafson for their input in the writing of this paper. We would also like to thank Jon

Raupp, Garret Kennedy and Katie Neugebauer-McRell for their assistance in the work.

This work is supported by USDA Agricultural Research Service CRIS 5430-20000-005D

and is a joint contribution of the USDA ARS and the Kansas Agricultural Experiment

Station. KAES contribution number: 13-017-J.

\section{REFERENCES}

Bockus WW, Appel JA, Bowden RL, Fritz AK, Gill BS, Martin TJ, Seifers DL, BrownGuedira GL, Eversmeyer MG (2001) Success stories: Breeding for wheat disease resistance in Kansas. Plant Dis 85:453-461.

Burrows M, Franc G, Rush C, Blunt T, Ito D, Kinzer K, Olson J, O’Mara J, Price J, Tande C, Ziems A, Stack J (2009) Occurrence of viruses in wheat in the Great Plains region. Plant Health Progress. doi:10.1094/PHP-2009-0706-01-RS.

Christian ML, Willis WG (1993) Survival of Wheat streak mosaic virus in grass hosts in Kansas from wheat harvest to fall wheat emergence. Plant Dis 77:239-242.

Cox, TS (1998) Deepening the wheat gene pool. J Crop Production 1:1-25.

Dunnett CW (1955) A multiple comparison procedure for comparing several treatments with a control. J Amer Stat Assoc. 50:1096-1121.

Dwyer GI, Gibbs MJA, Gibbs J, Jones RAC (2007) Wheat streak mosaic virus in Australia: relationships to isolates from the Pacific Northwest of the USA and its dispersion via seed transmission. Plant Dis 91:164-170.

Ellis MH, Reetzke GJ, Mago R, Chu P (2003) First report of Wheat streak mosaic virus in Australia. Austral Plant Path 32:551-553.

Friebe B, Gill KS, Tuleen NA, Gill BS (1996) Transfer of Wheat streak mosaic virus 
resistance from Agropyron intermedium to wheat. Crop Sci 36:857-861.

Friebe B, Qi LL, Wilson DL, Chang ZJ, Seifers DL, Martin TJ, Fritz AK, Gill BS (2009) Wheat-Thinopyrum intermdedium recombinants resistant to Wheat streak mosaic virus and Triticum mosaic virus. Crop Sci 49:1221-1226

Gill BS, Friebe B, Wilson DL, Martin TJ, Cox TS (1995) Registration of KS93WGRC27 Wheat streak mosaic virus-resistant T4DL·4Ai\#2S wheat germplasm. Crop Sci 35:12361237

Gill BS, Friebe B, Qi LL, Wilson DL, Raupp WJ, Fritz AK, Seifers DL, Martin TJ, Pumphrey MO (2008) Notice of release of KS08WGGRC50 Wheat streak mosaic virusand Triticum mosaic virus-resistant hard red winter wheat germplasm. Kansas St. Univ. Ag Exp Station Coop Ext Serv Release. Manhattan, KS.

Haley SD, Martin TJ, Quick JS, Seifers DL, Stromberger JA, Clayshulte SR, Clifford BL, Peairs FB, Rudolph JB, Johnson JJ, Gill BS, Friebe B (2002) Registration of CO960293-2 wheat germplasm resistant to Wheat streak mosaic virus and Russian wheat aphid. Crop Sci 42:1381-1382.

Jones MW, Boyd EC, Redinbaugh MG (2011) Responses of maize (Zea maize L.) near isogenic lines carrying $W s m 1, W s m 2$, and $W_{s m} 3$ to three viruses in the Potyviridae.

Theor Appl Genet 123:729-740.

Lage J, Skovmand B, Andersen SB (2002) Expression and suppression of resistance to greenbug (Homoptera: Aphididae) in synthetic hexaploid wheats derived from Triticum dicoccum-Aegilops tauschii crosses. J Econ Ent 96:202-206.

Lage J, Skovmand B, Andersen SB (2004) Field evaluation of emmer wheat derived synthetic hexaploid wheats for resistance to Russian wheat aphid (Homoptera: Aphididae). J Econ Ent 97: 1065-1070.

Lage J, Warburton ML, Crossa J, Skovmand B, Andersen SB (2003) Assessment of genetic diversity in synthetic hexaploid wheats and their Triticum dicoccum and Aegilops tauschii parents using AFLPs and agronomic traits. Euphytica 134:305-317.

Lay CL, Wells DG, Gardner WAS (1971) Immunity from wheat streak mosaic virus in irradiated Agrotricum progenies. Crop Sci 11:431-432.

Liu W, Seifers DL, Qi LL, Pumphrey MO, Friebe B, Gill BS (2011) A compensating wheat-Thinopyrum intermedium Robertsonian translocation conferring resistance to Wheat streak mosaic virus and Triticum mosaic virus. Crop Sci 51:2382-2390.

Lu H, Price J, Devkota R, Rush C, Rudd J (2011) A dominant gene for resistance to Wheat streak mosaic virus in winter wheat line C0960293-2. Crop Sci 51:5-12.

Ma H, Singh RP, Mujeeb-Kazi A (1995) Resistance to stripe rust in Triticum turgidum, 
T. tauschii and their synthetic hexaploids. Euphytica 82:117-124.

Martin TJ, Fritz AK, Seifers DL, Shroyer JP (2007) RonL hard white wheat. Kansas St Univ Ag Exp Station Coop Ext Serv Release L-926. Manhattan, KS.

Martin TJ, Harvey TL, Bender CG, Seifers DL (1984) Control of Wheat streak mosaic virus with vector resistance in wheat. Phytopath 74:963-964.

McKinney HH, Sando WJ (1951) Susceptibility and resistance to the wheat streak mosaic virus in the genera Triticum, Agropyron, Secale, and certain hybrids. Plant Dis Rep $35: 476-478$.

McMullen MD, Jones MW, Simcox KD, Louie R (1994). Three genetic loci control resistance to Wheat streak mosaic virus in the maize inbred Pa405. Mol Plant Microbe Interact 7:708-712.

Mujeeb-Kazi A, Fuentes-Davila G, Villareal RL, Cortes A, Rosas V, Delgado R (2001b) Registration of ten synthetic hexaploid wheat and six bread wheat germplasm resistant to Karnal bunt. Crop Sci 41:274

Mujeeb-Kazi A, Cortes A, Rosas V, Cano S, Sanchez J, Juarez L, Delgado R (2001a) Genetic diversity for improving scab resistance in wheat. In: Proc Warren E. Kronstad Symp, CIMMYT, Mexico pp. 126-129.

Narasimhamoorthy B, Gill BS, Fritz AK, Nelson JC, Brown-Guedira GL (2006) Advanced backross QTL analysis of a hard winter wheat $\mathrm{x}$ synthetic wheat population. Theor Appl Genet 112:787-796.

Price JA, Workneh F, Evett SR, Jones DC, Arthur J, Rush CM (2010) Effects of Wheat streak mosaic virus on root development and water-use efficiency of hard red winter wheat. Plant Dis 94:766-770.

Rahman F, Ross JG, Gardner WS (1974) Tolerance to Wheat streak mosaic virus in spring and winter wheat cultivars. Crop Sci 14:178-180.

Seifers DL, Martin TJ (1988) Correlation of low level Wheat streak mosaic virus resistance in Triumph 64 wheat with low virus titer. Phytopath 78:703-707.

Seifers DL, Martin TJ, Harvey TL, and Gill BS (1995) Temperature sensitivity and efficacy of Wheat streak mosaic virus resistance derived from Agropyron intermedium. Plant Dis 79:1104-1106.

Seifers DL, Martin TJ, Harvey TL, Haber S (2007) Temperature sensitive Wheat streak mosaic virus resistance acquired from KS03HW12 wheat. Plant Dis 91:1029-1033. 
Seifers DL, Martin TJ, Harvey TL, Haber S, Haley SD (2006) Temperature sensitivity and efficacy of Wheat streak mosaic virus resistance derived from C0960293 wheat. Plant Dis 90:623-628.

Slykhuis JT, Bell W (1963) New evidence on the distribution of Wheat streak mosaic virus and the relation of isolates from Rumania, Jordan, and Canada. Phytopath 53:23637.

Slykhuis JT (1955) Aceria tulipae Keifer (Acarina: Eriophyidae) in relation to the spread of Wheat streak mosaic. Phytopath 45:116-128.

Stenger DC, Hall JS, Choi I-R, French R (1998) Phylogenetic relationships within the family Potyviridae: Wheat streak mosaic virus and Brome streak mosaic virus are not members of the genus Rymovirus. Phytopath 88:782-787.

Stoddard SL, Lommel SA, Gill BS (1987) Evaluation of wheat germplasm for resistance to Wheat streak mosaic virus by symptomatology, ELISA, and slot-blot hybridization. Plant Dis 71:714-719.

Warburton ML, Crossa J, Franco J, Kazi M, Trethowan R, Rajaram S, Pfeiffer W, Zhang P, Dreisigacker S, van Ginkel M (2006) Bringing wild relatives back into the family: Recovering genetic diversity in CIMMYT improved wheat germplasm. Euphytica 149:289-301.

Zohary D, JH Harlan, and A Vardi (1969) The wild diploid progenitors of wheat and their breeding value. Euphytica 18:58-65. 
List of Tables and Figures

Table 1. CYMMIT synthetic lines selected from an initial screen for resistance to Wheat streak mosaic virus. Lines were tested in fall and winter greenhouses for two years. At 21 days post second inoculation, lines were visually scored for resistance based on a scale of $0-5$, where 0 is no symptoms and 5 is severe. LSMeans are based Dunnett-Hsu test. Lines were then tested in two growth chambers at $18{ }^{\circ} \mathrm{C}$ and $25{ }^{\circ} \mathrm{C}$ and also in greenhouse (GH) at temperatures ranging from $22-25{ }^{\circ} \mathrm{C}$ to determine temperature sensitivity on virus accumulation as measured by ELISA. .

Table 2. Line designations, other source numbers, aliases, and parentage of CYMMIT synthetic lines with levels of resistance to Wheat streak mosaic virus.

Figure 1. Wheat streak mosaic virus symptoms on six lines of wheat. Leaves are the third leaf above the inoculated, 21 days post second inoculation. Lines were then tested in two growth chambers at $18{ }^{\circ} \mathrm{C}$ and $25^{\circ} \mathrm{C}$ and also in greenhouse (GH) at temperatures ranging from $22-25^{\circ} \mathrm{C}$ Four lines are synthetic lines, meanwhile Tomahawk and WGGRC50 are susceptible and resistant controls, respectively.

Figure 2. Viral antigen accumulation at different temperatures of CYMMIT synthetic lines $07-S Y N-27$, SYN-106, SYN-164, and SYN-383 with levels of resistance to Wheat streak mosaic virus. WGGRC50 is a resistant comparison with the temperature sensitive resistance gene, $W s m 1$. 
Rupp et al.,

Page 16 
Table 1.

\begin{tabular}{|c|c|c|c|c|c|}
\hline \multirow[b]{2}{*}{ Line } & \multirow[b]{2}{*}{ LSMeans } & \multirow[b]{2}{*}{$\operatorname{Pr}>|t|$} & \multicolumn{3}{|c|}{$\underline{E L I S A ~ A b S}_{405}$} \\
\hline & & & $18^{\circ} \mathrm{C}$ & $25^{\circ} \mathrm{C}$ & $\mathrm{GH}$ \\
\hline 07 Syn-2 & 4.60 & 1.0000 & $3.0+{ }^{*}$ & $3.0+$ & $3.0+$ \\
\hline 07 Syn-23 & 4.20 & 0.9455 & $3.0+$ & $3.0+$ & $3.0+$ \\
\hline 07 Syn-27 & 3.40 & 0.0908 & 0.289 & 2.469 & 3.0+ \\
\hline 07 Syn-90 & 4.20 & 0.9455 & $3.0+$ & $3.0+$ & $3.0+$ \\
\hline 07 Syn-95 & 4.20 & 0.9455 & $3.0+$ & $3.0+$ & $3.0+$ \\
\hline 07 Syn-106 & 3.40 & 0.0908 & 0.388 & 3.0+ & 3.0+ \\
\hline 07 Syn-109 & 3.80 & 0.4329 & 2.021 & $3.0+$ & $3.0+$ \\
\hline 07 Syn-113 & 3.40 & 0.0908 & $3.0+$ & $3.0+$ & $3.0+$ \\
\hline 07 Syn-129 & 3.80 & 0.4329 & $3.0+$ & $3.0+$ & $3.0+$ \\
\hline 07 Syn-141 & 3.40 & 0.0908 & $3.0+$ & $3.0+$ & $3.0+$ \\
\hline 07 Syn-163 & 3.40 & 0.0908 & $3.0+$ & $3.0+$ & $3.0+$ \\
\hline 07 Syn-164 & 3.00 & 0.0107 & 0.315 & $3.0+$ & 3.0+ \\
\hline 07 Syn-180 & 4.40 & 0.9988 & $3.0+$ & $3.0+$ & $3.0+$ \\
\hline 07 Syn-181 & 3.80 & 0.4329 & $3.0+$ & $3.0+$ & $3.0+$ \\
\hline 07 Syn-200 & 3.40 & 0.0908 & $3.0+$ & $3.0+$ & $3.0+$ \\
\hline 07 Syn-209 & 3.47 & 0.2947 & 2.277 & $3.0+$ & $3.0+$ \\
\hline 07 Syn-212 & 4.81 & 1.0000 & $3.0+$ & $3.0+$ & $3.0+$ \\
\hline 07 Syn-234 & 3.47 & 0.2947 & 1.547 & $3.0+$ & $3.0+$ \\
\hline 07 Syn-255 & 4.81 & 1.0000 & $3.0+$ & $3.0+$ & $3.0+$ \\
\hline 07 Syn-256 & 3.80 & 0.4329 & $3.0+$ & $3.0+$ & $3.0+$ \\
\hline 07 Syn-258 & 4.20 & 0.9455 & $3.0+$ & $3.0+$ & $3.0+$ \\
\hline 07 Syn-283 & 2.60 & 0.0008 & $3.0+$ & $3.0+$ & 3.0+ \\
\hline 07 Syn-284 & 4.14 & 0.9757 & $3.0+$ & $3.0+$ & $3.0+$ \\
\hline 07 Syn-289 & 3.80 & 0.4329 & $3.0+$ & $3.0+$ & $3.0+$ \\
\hline 07 Syn-290 & 4.60 & 1.0000 & $3.0+$ & $3.0+$ & $3.0+$ \\
\hline 07 Syn-319 & 4.14 & 0.9757 & $3.0+$ & $3.0+$ & $3.0+$ \\
\hline 07 Syn-348 & 3.40 & 0.0908 & $3.0+$ & $3.0+$ & $3.0+$ \\
\hline 07 Syn-358 & 2.81 & 0.0203 & $3.0+$ & $3.0+$ & 3.0+ \\
\hline 07 Syn-376 & 2.81 & 0.0203 & $3.0+$ & $3.0+$ & 3.0 + \\
\hline 07 Syn-382 & 4.14 & 0.9757 & $3.0+$ & $3.0+$ & $3.0+$ \\
\hline 07 Syn-383 & 2.20 & $<.0001$ & 0.184 & $3.0+$ & 3.0+ \\
\hline Tomahawk & 5.00 & 1.0000 & $3.0+$ & $3.0+$ & $3.0+$ \\
\hline WGRC50 & 1.40 & $<.0001$ & 0.176 & $3.0+$ & $3.0+$ \\
\hline WGRC27 & 1.80 & $<.0001$ & & & \\
\hline RonL & 1.60 & $<.0001$ & & & \\
\hline Bobwhite & 5.00 & 1.0000 & & & \\
\hline
\end{tabular}

* Absorbance exceeded maximum measurable value of 3.00 
Table 2.

\begin{tabular}{|c|c|c|c|}
\hline Line No. & $\begin{array}{c}\text { Source } \\
\text { Identification }\end{array}$ & Aliases & Pedigree \\
\hline 07 Syn-27 & CIGM88.1195-0B & $\begin{array}{l}\text { SYN-28; CID159526; } \\
\text { BW27741 }\end{array}$ & SORA/Ae. tauschii [WX208] \\
\hline 07 Syn-106 & CIGM88.1335-0B & $\begin{array}{l}\text { SYN-111; CID159578; } \\
\text { BW27824 }\end{array}$ & SCOOP_1/Ae.tauschii [WX434] \\
\hline 07 Syn-109 & CIGM88.1343-0B & $\begin{array}{l}\text { SYN-114; CID159581; } \\
\text { BW27827 }\end{array}$ & DOY1/Ae. tauschii [WX446] \\
\hline 07 Syn-164 & CIGM89.569-0Y & $\begin{array}{c}\text { SYN-170; CID160221; } \\
\text { BW27883 }\end{array}$ & $\begin{array}{l}\text { 68.111/RGB-U//WARD/3/FGO/4/ } \\
\text { RABI/5/Ae.tauschii }[\mathrm{WX} 900]\end{array}$ \\
\hline 07 Syn-209 & CIGM89.567-1B & $\begin{array}{l}\text { SYN-216; CID161079; } \\
\text { BW27929 }\end{array}$ & CETA/Ae. tauschii [TA2468; WX895] \\
\hline $\begin{array}{l}07 \text { Syn-234 } \\
\text { PI } 648688\end{array}$ & CIGM90.841 & $\begin{array}{l}\text { SYN-244; CID161587; } \\
\text { BW27957; NSGC } 9783\end{array}$ & $\begin{array}{c}\mathrm{YAV} 79 / / \mathrm{DACK} / \mathrm{RABI} / 3 / \mathrm{SNIPE} / 4 / \text { Ae. } \\
\text { tauschii }[\mathrm{WX} 490]\end{array}$ \\
\hline $\begin{array}{l}07 \text { Syn-358 } \\
\text { PI } 648812\end{array}$ & CIGM93.211 & $\begin{array}{l}\text { SYN-383; CID161711; } \\
\text { BW28096; NSGC } 9922\end{array}$ & DOY1/Ae. tauschii [WX264] \\
\hline $\begin{array}{l}07 \text { Syn-376 } \\
\text { PI } 648829\end{array}$ & CIGM93.233 & $\begin{array}{l}\text { SYN-402; CID161730; } \\
\text { BW28115; NSGC } 9941\end{array}$ & $\begin{array}{c}\text { CPI/GEDIZ /3/ GOO // JO69 / CRA } \\
\text { /4/ Ae. tauschii [WX390] }\end{array}$ \\
\hline $\begin{array}{l}07 \text { Syn-383 } \\
\text { PI } 648836\end{array}$ & CIGM93.240 & $\begin{array}{l}\text { SYN-410; CID161738; } \\
\text { BW28123; NSGC } 9949\end{array}$ & $\begin{array}{l}\text { STY-US/CELTA//PALS/3/SRN_5/4/ } \\
\text { Ae.tauschii [WX418] }\end{array}$ \\
\hline
\end{tabular}


Figure 1.

$18{ }^{\circ} \mathrm{C} \quad 25{ }^{\circ} \mathrm{C} \quad \mathrm{GH}$
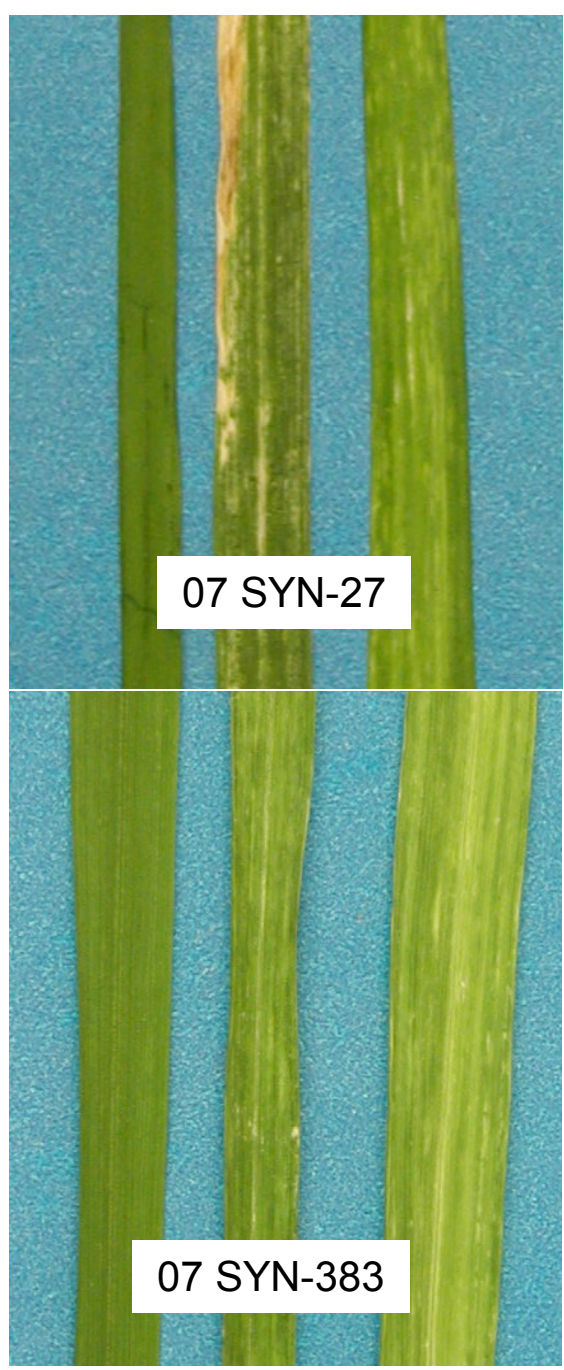

$18{ }^{\circ} \mathrm{C} \quad 25^{\circ} \mathrm{C} \quad \mathrm{GH}$
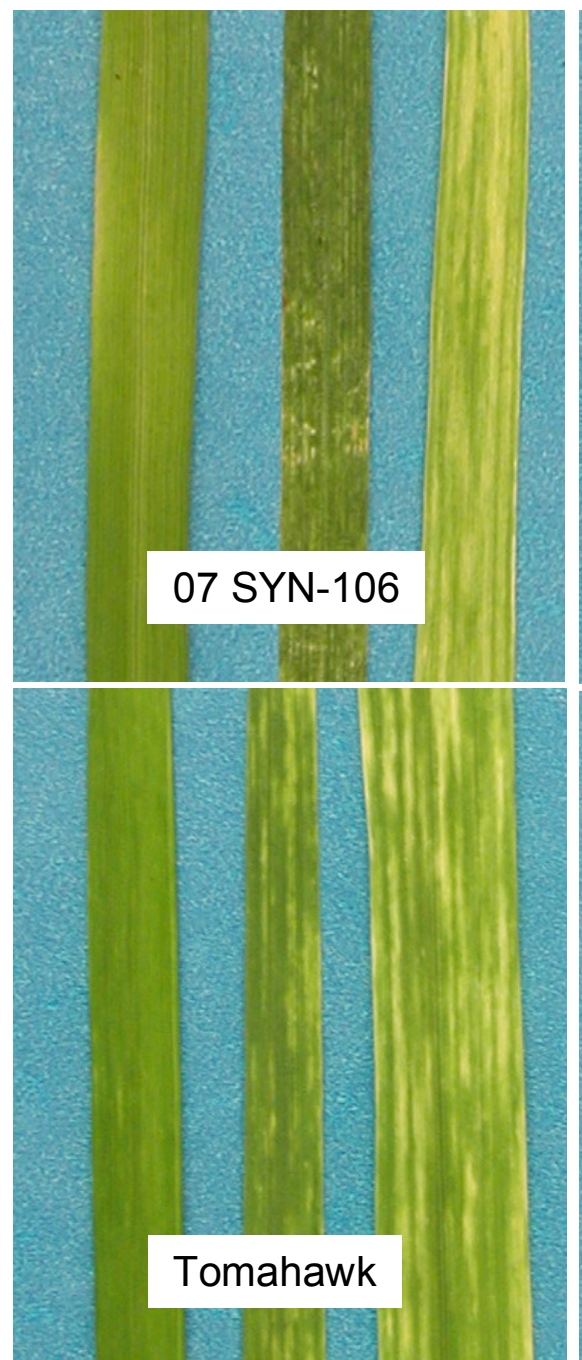

$18^{\circ} \mathrm{C} \quad 25^{\circ} \mathrm{C} \quad \mathrm{GH}$
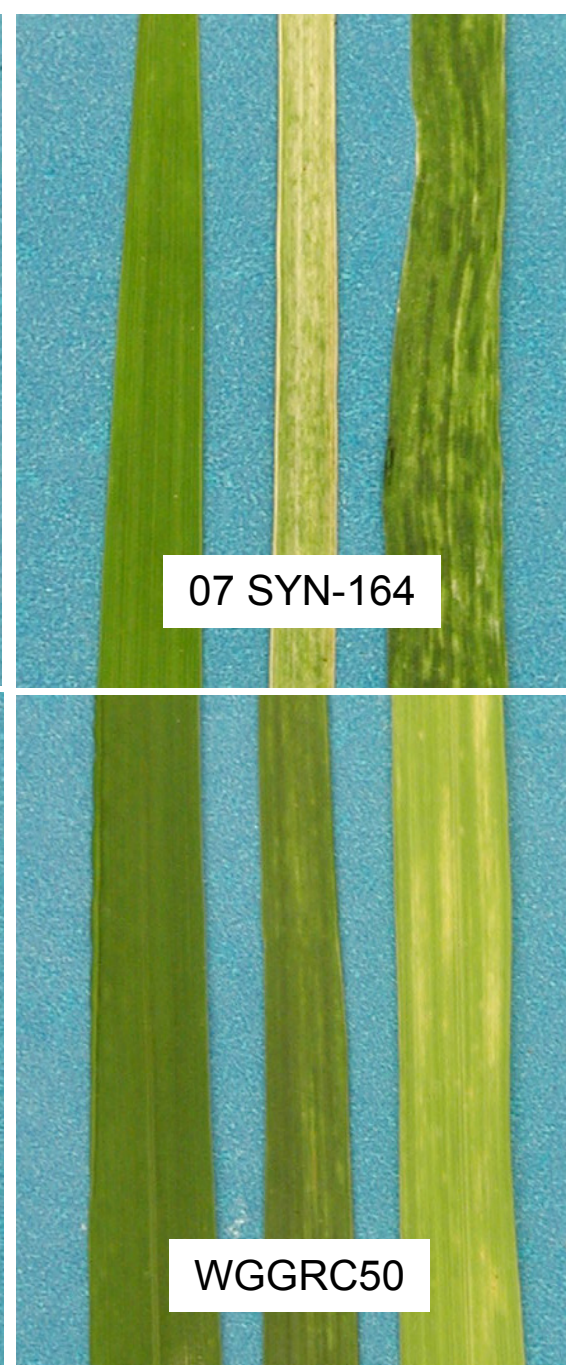
Figure 2.

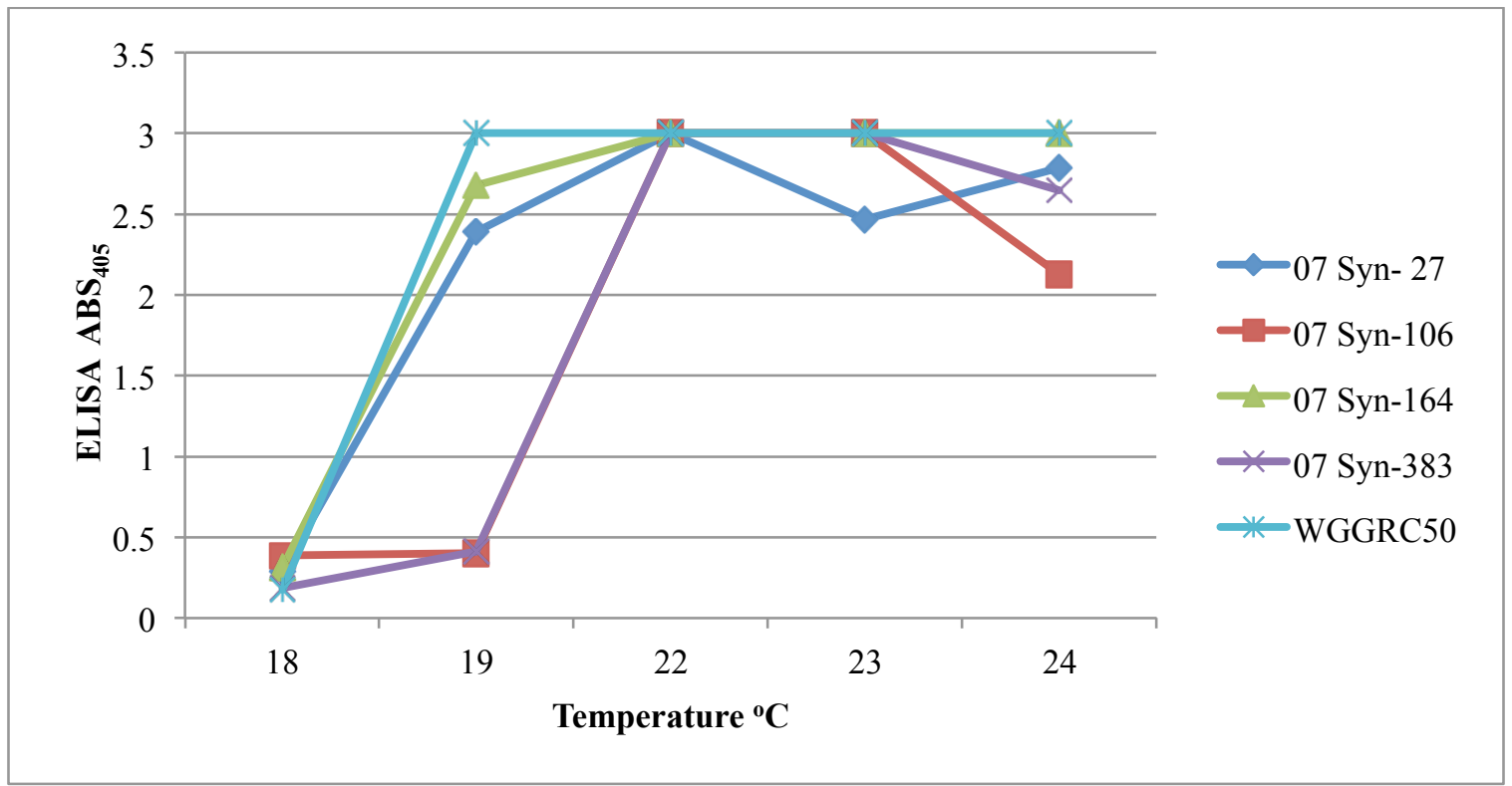

